\title{
FINANCIAL SYSTEM FOR A MULTINATIONAL FAMILY IN SHARIA AND LAW
}

\section{YOUSF FARAJ MOHAMED HADIRI}

Alumni Doctorate Program at State Islamic University of Surabaya

Email: yousf.hadiri@gmail.com

\begin{abstract}
The issue of the financial system of a multinational family in shari'a and law is of great importance in the current era of the deterioration of rights in the case of family disputes, which often result in divorce. Hence, Islamic law has taken into account this subject with many rules and provisions that protect both spouses' rights and obligations. Some Arab countries have also taken this approach, but they have not been far from international laws that advocate women's freedom, as we find in Tunisian law, for example. Here we have examined this subject from a legitimate legal point to clarify the problem that some countries have occurred when they put the family laws.

The family laws have come up with sub-solutions that have made them fundamental issues that would raise the status of women and strengthen their legal and social status. This is the result of satisfying the demands of a predominantly political nature of religion, which made some laws rigid. The obligation of positive laws should not be affected by the purposes of Islamic law and its lofty principles of political, because codification does not prohibit Hara'am things, and it is not Hara'am for Halaal and non-ijtihad.
\end{abstract}

Keywords: Financial System, Multinational Family, Sharia and Law

\section{Introduction}

Islam came with truth and justice, to manage every day's life for good trail, give people their due rights, fair, accuracy, and depth, and financial, social, political sections and other. It cared about the Islamic preservation of family which is the basis of human society, and the nucleus of Nations and peoples, meant most diligence, set them up on a solid foundation of love, peace, and stability. Islam has called for marriage and encourage people to go through this experience, and made a lasting relationship between the spouses, lovely it is a sacred and thick emotional connection between men and women with a basic of respect and appreciation to bring love and affection between them.

Since Islam is a religion of Justice and equality, strengthening family ties and provides the statement of rights of each other, as decided by the penalty box which guarantees the maintenance of these rights, ensured that women's rights in all aspects and fields, and maintained as a sister and a daughter and a wife. 
It is the most important rights which necessitated in the Islamic family law section for the wife, the dowry and alimony right, as stated in the Qur'an and Sunnah, which prove it once the marriage, and the husband should provide that with what is asked by the wife.

The international conventions and norms at the international level have tended to focus on the rights of the family to injustice and oppression, and in this area the text of Chapter 23 of the International Covenant on Civil and political rights provides that States parties to the present Covenant shall take appropriate measures to ensure equal rights and responsibilities of spouses as to mating and during marriage and upon divorce. It also recommends that the International Convention on the Elimination of all forms of discrimination against women in its Chapter vi provides that States parties shall take all appropriate measures to eliminate discrimination against women in all matters relating to marriage and family relations and in particular shall ensure the same rights for both spouses in the form of ownership, acquisition and property management and disposition.

It should be noted that the problems faced by the family in international law lies in determining the financial relationship of the couple, there are some countries that take Western laws that stray from the spirit of Islamic law in this regard, Tunisian law which had taken the course of French law by approving financial disclosure unit between spouses.

The problems faced by the family in international law lies in determining the financial relationship of the couple, In terms of independence or financial disclosure. The problem posed by financial disclosure unit in terms of assigning spent on home after marriage, after the dissolution of the marriage, and how to be adapted.

- Question: How both Sharia and look at the financial regulations for multinational family?

- $\quad$ Research methodology: This study relied on descriptive analytical approach, using the inductive method.

- $\quad$ Research objective: Determining the law applicable to mixed marriage's matter and its dissolution in the international community on social justice and family based on the Islamic law (Sharia).

\section{Multinational Family}

The researcher can manifest what multinational family through intermarriage concept statement in private international law, then refer to the concept of multiple nationalities statement to show legal status of multinational for family financial relationship. 
1. The concept of mixed marriages: Mixed marriages in private international law, is that marriage where both husband and wife have different the nationality, each one of them has a nationality unlike the other.

2. The concept of multinationality: Is that a person holds more than one nationality at the same time, in accordance with the Act of two or more. It can be said that the multinational is for the individual having more than one nationality, enjoy it at one time. So, it's mean: "Legal status where the same person have two or more nationality, so legally considered nationals of each country has its nationality".'

Multinational status: International agreements and legislation agreed that in case of conflict of nationalities and one of these nationalities nationality judge, judge law shall apply before it conflict. But if the nationality of a judge before it the conflict within one of these nationalities, I decided the Hague Convention of 1930, saying: "If someone have more than a nationality, it treats on the territory of the State of nationality not based on sexual preference the State where the regular residence or the nationality of the State indicated by circumstances that are more linked than others".2

\section{The financial system of the couple}

The financial system is one of the most important physical aspects and vitality, it cared about ancient and contemporary legislation, as it is no stranger to Islamic law. Arabic organizations have resorted to the provisions for financial relations between spouses and its affect by religious and moral values. And financial regulations for the couple is the rules governing financial relations between spouses. The financial relations between spouses in the Islamic system does not correspond to those financial regulations legislated by the French law which lay in uniting the patrimony between spouses. Islamic and Arabic laws know only one system which lies in the separation of the couple's financial liabilities, as well as add to other financial consequences of marriage.

1. What is the financial system for the couple: The concept of system in Islamic law means the principles and rules legislated by Allah to organize life in all fields to achieve the happiness. The couple's financial system is a

\footnotetext{
1. Ahmed Salamah, Privet International Islamic Law, 167.

2 . Mohammed Allafi, Conflict of laws and conflicts of international jurisdiction, 128.

3 . Ahme Al-Nagar, Women's rights in Islamic law, 200.
} 
set of rules that make up the legal regime governing estates, during marriage and at its dissolution, and consulted in determining financial couple relationship. So, it is determined by the financial system legal status of spouses and the duration of use in common life, of either spouse owned before marriage or during marriage. ${ }^{4}$

2. The principle of separation of the couple: Unique separation of the liabilities of the spouses in Islamic law to distinguish it from properties that the principle established in French law. In French law the husband keeps his own money if he wanted, but dispose of it without the participation of a wife, each one of them financially separated. But in the Islamic law (Sharia), the wife keep retains her rights and authority at her disposal without being obliged to contribute money in the cost of living and upbringing. So, Islamic law and Arabic laws gave the wife freedom to act in her own field.

Most Arabic legislation the principle of separation of the couple, so that each financial independence from the other article 37 of the Algerian family code: "each spouse financially independent from the other, but the spouses may agree in the marriage contract or at a formal contract later, about their common funds, which the spouses acquired during married life and determine the proportions that devolves into each of them".

\section{A. The wife's authority over her money in Islamic law:}

The Islamic Shari'a has clarified that marriage does not affect the wife's eligibility. The rightful wife is entitled to act in her own money with mosquitoes or without compensation, and she does not need her husband. If the wife is a minor, the husband does not guide her to dispose of her money, but she has the right to dispose of her and manage her financial affairs for the guardian.

a. Financial authority of the wife fully qualified: The public decided that the wife had the right to dispose of her own money as before marriage, but the "Maalikis" disagreed with some of the actions taken by the wife without

\footnotetext{
${ }^{4}$. Ahmed Muslim, Foreign personal family legal system, 126.

5 . Ahmed Muslim, 100.

${ }^{6}$. BlhajAlarabi, Brief explanation of the Algerian family law, 164.
} 
compensation. The audience based their words on the verse in Surat alNisaa, Allah said:

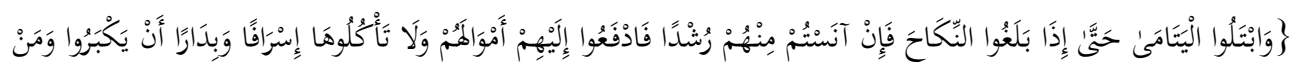

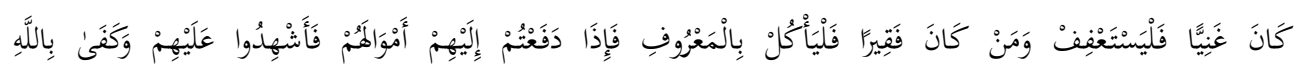

Surah al-Nisaa, 6.

This verse indicates that the stone is only for the orphans. Similarly, for a woman, if she is rational, her money must be paid to her, and the stone should be taken away from her, so she is free to dispose of it. ${ }^{7}$

b. The actions of the minor wife: If the wife is a minor since she is under the supervision of the guardian, she has to manage the money, and the husband is not entitled to guide them or to manage their money. The financial mandate means "supervising the financial affairs of the wife who is limited to keeping her money and developing it and fulfilling his rights and spending it as required". According to the provisions of the Islamic Shari'a, the father has full authority over the administration and disposal of small money. It is true for the judge to annul him in the case of this injustice.

Summary of the above that the wife has her absolute freedom on her money entitled to dispose of it as it happened, except those restrictions provided by the "Maliki" doctrine and related to the permission of her husband in some behaviors. Moreover, the minor wife does not have income for her husband in the state or her money, and the guardian remains the father responsible for her administration because Islamic law does not know what is called in French law rationalization. ${ }^{8}$

B. The wife's authority over her money in laws: Most of the Arab legislations have taken the principle of separation of the couple's money by providing that each of them has a separate financial obligation. Article 37 of the Algerian Family Code provides that: "Each spouse has a separate financial obligation, but the spouses may agree in a contract Marriage or in a subsequent formal contract, to have their funds in common in other words they give access for each other to join

\footnotetext{
7 - Abu Barakat, Ahmed Al-Dardair, Al-Sharh Al-Kabir, (Beirut, Dar Al-Fikr, 307).

8 - Hamdi, Kamal, The Substantive Provisions of the State on Money, (Alexandria, Establishment of Knowledge, 38).
} 
financially, acquired during the marital life and determine the proportions that belong to each of them". Through this article it is clear that the Algerian legislator has taken the path of the public with the independence of the wife's financial responsibility and the husband's non-interference in her money, but this is subject to the condition that if they are agreed in the marriage contract or in an independent official contract. ${ }^{9}$

\section{Common property of spouses}

\section{A. Wife's Involvement in Financial Spending According to Islamic Law: ${ }^{10}$}

The Islamic law asked the husband must give his wife anything she wants, Allah said in Qur'an:

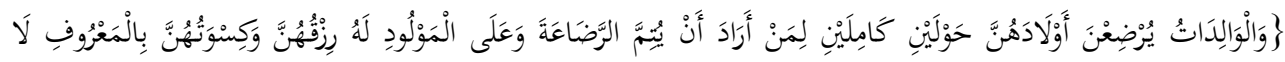

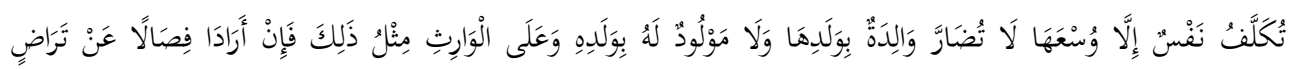

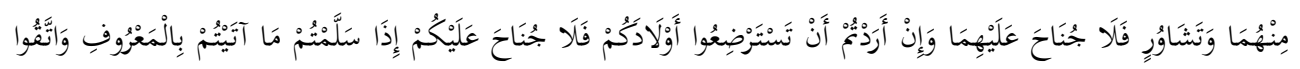

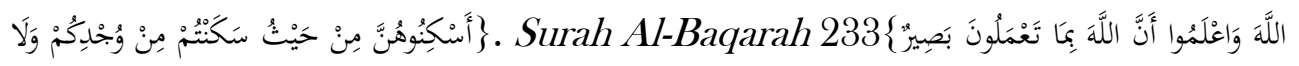

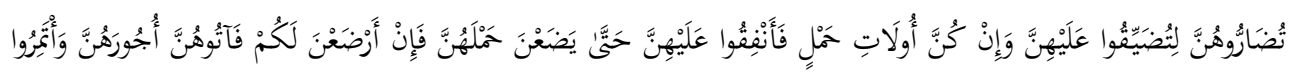

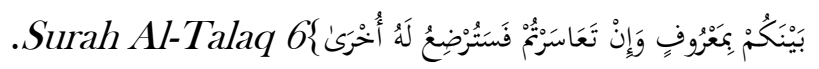

Most Arabic laws adopted the system of financial separation of the couples, it is stated that it is a must for the husbund to pay in all needs of life. Under this principle, article 74 of the Algerian family code by saying, "The wife must be expended by her husband since they got married and there is an evidence taking into account the provisions of articles 78-79-80 of this law." We find in this text that the Algerian legislature adopted the correct contract obligation to spend on one pair which is the husband, that the wife lead herself to her husband to make live and to enjoy themselves, this thing was confirmed by the Algerian justice that alimony is connected to the right". ${ }^{11}$

Also, this is the right decision in law No. 10 of 1984 concerning the Libyan personal status provisions, article 22 of the Act on it, "answered alimony

\footnotetext{
9 - Al-Arabi, Belhadj, Al-Wajeez in explaining the Algerian Family Law, (Algeria, 1999, 164). Al-Rashed, Ben-Shuyoukh, The amended Algerian Family Law, (Algeria, Dar al-Khalduniya, 2008, 61).

10 . Mohammed Alshnori, Subscribe to a theory of religion in Islamic law-a comparative study, 101.

11 . Masudi, Rashid, The financial system for the couple in Algerian legislation, 252.
} 
solvent from the date of the contract on her husband's right". The Libyan legislature has Islamic law on obligatory for the husband and the distribution of responsibilities of the family, because men can earn by seeking out and requested the provision of available means and in different circumstances of life.

\section{B. The Contribution of the Wife to Expenditure}

In the era of globalization and the entry of women in career and work, and the consequent effects on financial ties to the wife and everything she spend money and incentives, resulting in some wife sharing family's responsibilities of maintenance on the House and the kids as well as their contribution to increase the family fortune. It is a burden and costs involving women's expenses for the management of the home and raising children, and all that is necessary for the needs of the family. Islamic law (Sharia) gave women's freedom began to dispose of her money and not obliged to share with her husband in the House, but the economic conditions and the difficult life in many families currently has made the wife help her husband in charge of spending at home. ${ }^{12}$ To resolve a dispute that may arise between the couple about how committed everyone spending at home, it must be specified in the contract, leaving the wife can continue to function and to be hers between her husband and her family in half.

Libyan law stated like other Arabic laws regarding the involvement of the wife in the family spent alone provided that the husband pinching cannot bear all the burdens of his family be so expenses, as stipulated in article 22 of law No 10 of 1984 concerning marriage and divorce provisions of Libya by saying, "The alimony must be on her husband right decade history of solvent and solvent wife spending on her husband and children of a spouse's insolvency, and alimony as if their binding imposed time difficult or easier".

\section{Contribution of the Wife Spending}

The emergence of the era of globalization and the entry of women in the workforce and external work, and the consequent effects in the financial relations of the wife and all the money she spent and incentives, led to the participation of the

12. Ahmed Al-Nagar,250.

13. Said Al-jleadi, The provisions of the family in marriage and divorce and their tracks, 314 . 
wife in some family burdens of the expense of the house and children as well as their contribution to the increase of family wealth. The burdens and costs involved by women are the expenses of housekeeping and child-rearing, and all that is necessary for the needs of the family.

The position of Islamic law on the contribution of the wife to spend: The Islamic Shari'a law has allowed woman to dispose of her money and is not obliged to share with her husband to spend on the house. However, the economic conditions and difficult life that many families are currently experience having the wife share her responsibility for spending for the house. But to resolve the dispute that may arise between the spouses about the commitment of each individual to spend on the house must be specified in the contract, and leave the wife to continue in her job and be paid between her husband and her family equally. ${ }^{14}$

A- The position of Arab legislation on the contribution of the wife spending: Some Arab legislation offered to involve the wife in spending process. The general rule of the Algerian legislator, which is provided in article 36 of the Family Code, is: "Cooperation in the interest of the family, the welfare and well-being of the children". In general, this provision imposes the spouses the duty to observe the raising of their children and to do family affairs and what is required by the interest.

B- Article 76 of the Algerian Family Code states: "In the event of a father's incapacity, the maintenance of the children shall be paid to the mother if she is able to do so." After careful consideration of the two texts mentioned above we can say that the Algerian legislator has referred to the contribution of the wife in spending, but this was not binding on the wife, except in the case which the husband's inability and inability to spend. The Libyan law, like other Arab laws, also applies to the participation of the wife in spending on the family alone, provided that the husband is insolvent and can not afford all the expenses of the house. This is stated in Article 22 of Law No. 10 of 1984 on the provisions of marriage and divorce: The husband's expense on the husband's wife from the date of the right contract, and obliges the wealthy wife to spend on her husband and children from him the

14 - Najjar, Ibrahim Abdel Hadi Ahmed, (Women's rights in Islamic law, 250). 
duration of the husband's insolvency, and estimated maintenance according to the condition of the obligor at the time of imposition of hard or easy.

\section{Conclusion}

The family laws have come up with sub-solutions that have made them fundamental issues that would raise the status of women and strengthen their legal and social status. This is the result of satisfying the demands of a predominantly political nature of religion, which made some laws rigid. The obligation of positive laws should not be affected by the purposes of Islamic law and its lofty principles of political, because codification does not prohibit Hara'am things, and it is not Hara'am for Halaal and non-ijtihad.

\section{References}

Abu Barakat, Ahmed Al-Dardair, Al-Sharh Al-Kabir, Beirut, Dar Al-Fikr, Ahme Al-Nagar, Women's rights in Islamic law, 1995.

Ahmed Muslim, Foreign personal family legal system, 1966.

Ahmed Salamah, Privet International Islamic Law, 1989.

Al-Arabi, Belhadj, Al-Wajeez in explaining the Algerian Family Law, Algeria, 1999 .

Al-Rashed, Ben-Shuyoukh, The amended Algerian Family Law, Algeria, Dar al-Khalduniya, 2008.

BlhajAlarabi, Brief explanation of the Algerian family law, 1999.

Hamdi, Kamal, The Substantive Provisions of the State on Money, Alexandria, Establishment of Knowledge.

Masudi, Rashid, The financial system for the couple in Algerian legislation,

Mohammed Allafi, Conflict of laws and conflicts of international jurisdiction 2000.

Mohammed Alshnori, Subscribe to a theory of religion in Islamic law-a comparative study, 1985.

Najjar, Ibrahim Abdel Hadi Ahmed, Women's rights in Islamic law, 1995.

Said Al-jleadi, The provisions of the family in marriage and divorce and their tracks, 2019. 